49 | 2018

Human-environment relationships in Siberia and Northeast China. Knowledge, rituals, mobility and politics among the Tungus peoples, followed by Varia

\title{
Are the Evenki reindeer herders still nomads? The alternate use of different types of spaces in Inner Mongolia, China
}

Les Évenks éleveurs de renne sont-ils encore nomades? L'utilisation alternée de différents types d'espaces en Mongolie-Intérieure, Chine

\section{Aurore Dumont}

\section{(2) OpenEdition} Journals

Electronic version

URL: https://journals.openedition.org/emscat/3398

DOI: $10.4000 /$ emscat.3398

ISSN: 2101-0013

Publisher

Centre d'Etudes Mongoles \& Sibériennes / École Pratique des Hautes Études

Electronic reference

Aurore Dumont, "Are the Evenki reindeer herders still nomads? The alternate use of different types of spaces in Inner Mongolia, China", Études mongoles et sibériennes, centrasiatiques et tibétaines [Online], 49 | 2018, Online since 20 December 2018, connection on 13 July 2021. URL: http:// journals.openedition.org/emscat/3398 ; DOl: https://doi.org/10.4000/emscat.3398

This text was automatically generated on 13 July 2021.

(c) Tous droits réservés 


\section{Are the Evenki reindeer herders still nomads? The alternate use of different types of spaces in Inner Mongolia, China}

Les Évenks éleveurs de renne sont-ils encore nomades? L'utilisation alternée de différents types d'espaces en Mongolie-Intérieure, Chine

Aurore Dumont

\section{EDITOR'S NOTE}

Map of the repartition of the Evenki in Russia and China

click here

Positions of the case studies in the present volume

click here

The "Ecological Migration" of the Evenki from old Aoluguya to new Aoluguya in 2003 (Xie, this volume)

click here

\section{Introduction}

1 According to a widely accepted but contested definition, nomadic pastoralism is an economy relying on livestock and on extensive seasonal movements conducted by herders together with their livestock. It encompasses a broad range of skills, techniques and values shared by the people who practice it. Throughout the $20^{\text {th }}$ century, state policies, the market economy and environmental issues gave rise to important changes in nomadic pastoralism. In The End of Nomadism?, Caroline Humphrey and David Sneath argue that while "nomadism has disappeared virtually 
everywhere in Inner Asia, mobility remains a central pastoral technique" (Humphrey \& Sneath 1999, p. 1).

2 In the People's Republic of China (PRC), the sedentarisation campaigns introduced from the 1950s, together with pasture degradation and policies of modernisation, have profoundly affected the domestic economies of millions of nomadic people. In the Tibetan Plateau, herders had to abandon their pastures and settle down in special resettlements to revitalise the degraded grassland (Cencetti 2010, p. 45), while in the Xinjiang Autonomous Region there has been a "swing between nomadism and sedentarism among the Kazakh, Mongols, Kirghiz, Tajik and Uyghur nomadic herders" (Tsui 2012, p. 65). In the Inner Mongolia Autonomous Region, the combined effects of various state policies have also affected the Evenki reindeer herders and the Mongols. Nowadays, the constant movement of the herders between their "ethnic village ${ }^{1 "}$ "and their camps in the forest not only reflects their strategies for adapting to ecological and political challenges, but also sheds light on the local government's impotence when it comes to resolving what is called locally "settling but not living" (Ch. ding er bu ju 定而不居). Today, are the Chinese Evenki reindeer herders of China still practising nomadic pastoralism?

\section{Nomadism(s)?}

3 The viability of the concept of "nomadism" has been called into question by scholars, since it has always referred to "a romantic stereotype [...] which viewed nomadic pastoralists as brave, independent fierce men, freely moving with their herds and not having to deal with the constraints and frustration we ourselves face in day-to-day "civilised living"' (Dyson-Hudson \& Dyson-Hudson 1980, p. 15). Although the term "nomadism" is "a category imagined by outsiders" (Humphrey \& Sneath 1999, p. 1) and has not been adopted by the people concerned to refer to themselves - the Evenki would instead use the words "Evenki" to refer to their community-, it remains a functional concept in anthropological work for analysing the local knowledge of mobile reindeer herding. Indeed, herding and hunting skills, land management, the organisation of mobility and cultural values form a complex range of nomadic practices which are highly valued by the Evenki and are still part of their everyday practices. While "nomadism" and its related lifestyle, as witnessed by ethnographers and other observers (such as Serguei Shirokogoroff [1929] 1966, Ethel John Lindgren 1930, 1938, Haruka Nagata/Yong Tianzhen [1969] 1991 and Anatoli Kaigorodov 1968²) in the first decades of the last century, may have already gone extinct, nomadic practices are still being transformed and adjusted. In their volume dedicated to the pastoral societies of Northern and Central Asia, Charles Stépanoff, Carole Ferret, Gaëlle Lacaze and Julien Thorez (Stépanoff et al. 2013) highlight the different forms of nomadism in the area and the range of practices covered by the term "nomadism".

4 Without ignoring local emic conceptions, in the present case study, I will consider the global concept of nomadism as an ongoing process in which people move from one space to another in accordance with the needs of the reindeer herds. From this perspective, nomadism is not opposed to sedentarism: the herders' ethnic village and the seasonal camps are embedded entities which allow for constant adjustments to reindeer herding. 
5 Based on fieldwork conducted between 2008 and 2016 among the Evenki reindeer herders in Hulun Buir ${ }^{3}$, this paper seeks to understand how the herders adapt reindeer herding and the required mobility to a changing social and economic environment in the present-day Inner Mongolia Autonomous Region. More precisely, it explores the Evenki's annual movements between two complementary spaces: the ethnic village and the seasonal camps.

6 After presenting the Evenki reindeer herders of China and outlining the different state policies carried out from the 1950s, the first section exposes the herders' conception of two living spaces, the village and the camp. The second section examines the way the herders annually cover and use these two types of spaces.

\section{The Evenki reindeer herders of China}

7 The Evenki reindeer herders today form a small community of approximately 300 people 4 living with around 1,000 reindeer in the northeastern part of the Hulun Buir prefecture (Ch. Hulunbei'er shi 呼伦贝儿市) in the Inner Mongolia Autonomous Region. In the Chinese ethnographic literature and sources, they are known under various appellations: "Reindeer Evenki” (Ch. Shilu ewenke 使鹿鄂温克), “ReindeerUsing Tribe” (Ch. Shilu bu 使鹿部), “Yakut Evenki” (Ch. Yakute Ewenke 雅庫特鄂溫克) or “Aoluguya Evenki” (Ch. Aoluguya Ewenke 敖鲁古雅鄂温克). Nowadays, they are commonly known in the mass media as "Aoluguya Evenki", after the name of their current "ethnic village", or simply "People of Ao Village (Ch. Aoxiang ren 敖乡人). "Aoluguya" is the Chinese transliteration of the Evenki term "Oluia", meaning "lush poplar forest" and was chosen in the 1960s by the local Chinese administration to designate the newly created "ethnic village". The Evenki people use the ethnonym "Evenki" or the administrative category "Aoluguya Evenki" to refer to themselves. In order to avoid confusion, we will use the auto-ethnonym "Evenki" throughout the article to refer to the Evenki reindeer herders.

Today, the Evenki language is spoken only by a few elders. Most of the Evenki people only speak Mandarin, although they may use some Evenki terms when talking about topography or herding and hunting techniques. Furthermore, the Evenki have borrowed numerous terms from Russian, especially at the beginning of the $20^{\text {th }}$ century when the herders were engaged in barter trade with Russian emigrants settled in the area.

9 The Evenki were living in Southeast Siberia before crossing the Chinese border between the early $18^{\text {th }}$ and $19^{\text {th }}$ centuries in order to avoid Russian taxes and to find better hunting grounds. Although they were converted to Russian Orthodoxy, the Evenki practiced shamanism. Up to the 1930s, each clan had its own shaman (Kaigorodov 1968, Heyne 1999), whose function was to act to the benefit of the community: bringing success in hunting, curing sickness and accompanying the soul of the deceased (Heyne 1999, pp. 378-379).

10 Before the Chinese state launched its policies in the 1950s, the Evenki mode of subsistence relied primarily on an equal combination of herding and hunting. The herds of domesticated reindeer were usually small. The animal was used for milking, riding and packing: its meat was, and still is not eaten. The Evenki used to hunt roe deer, weasel, squirrel, wood grouse and sable. Apart from the sable, which was kept for barter with Russian emigrants up until the 1950s, the other types of game were 
consumed by the Evenki themselves for food and clothing. Similar to the Siberian taiga, the forest area of the Great Khingan range in Hulun Buir offers birch, larch, pine and the other natural resources needed for herding and hunting. Shaped by hills and mountains, the hydrographic network is made up of hundreds of rivers, lakes and streams. Drawing a natural border between Russia and China in the north, the Amur River is formed by the meeting of the Shilka and the Argun rivers. The Gen River runs through Aoluguya Village and flows into the Argun.

\section{"Settling but not living"}

11 The last six decades of Chinese state policies have transformed the Evenki's small-scale herding economy into an intensive type of herding management, which consists of a more systematic use of fixed dwellings and the reduction of grazing areas. This could be considered as the disappearance of the Evenki nomadic way of life. However, while the reduction of pastoral grounds and the low frequency of nomadisations is an undeniable reality today, herders' mobility has conversely become more flexible and herding skills remain a fundamental component of their everyday life. In 2003, the local authorities engaged in the "Ecological Migration" project (Ch. shengtai yimin 生态移民5), which consisted of banning hunting and relocating people and their herds $250 \mathrm{~km}$ south from their previous living area. The aim of this policy was officially to protect the environment and to improve the economic living conditions of the herders through proximity to an urban centre, sedentarisation and the development of ethnic tourism. The lack of appropriate grazing lands ended in the death of many reindeer. Faced with this serious catastrophe, the local authorities had to make a concession and allow the herders to go back to their camps to safeguard reindeer herding. 15 years after the "Ecological Migration", a large number of Evenki still move between the village and their winter and summer camp throughout the year, adapting their nomadisation routes and herding practices to external pressures, including environmental degradation, difficulties in accessing pastures and the growing number of Han Chinese tourists during the summer period. This is the concept of "settling but not living". Since that time, the only reindeer herders of the country have been given attention by the Chinese media, anthropologists, journalists and, later, tourists, all of whom were concerned or curious about this failed ecological policy.

\section{Chinese state policies and the nomads}

12 Central policies aimed at integrating nomadic peoples into the "modernised world" have always been a constant goal for nation states. As part of this political process, the first years of the PRC were devoted to new territorial planning and socio-economic development in pastoral areas ${ }^{6}$. From the 1950s onwards, like the other "ethnic minorities" of the country, the Evenki were incorporated into the new communist and multiethnic Chinese nation state. In theory, preferential policies towards ethnic minorities promoted an "integrated society" by setting up autonomous areas, supporting their socio-economic development, and preserving ethnic language and culture with financial aid ${ }^{7}$.

13 Following the Soviet political model implemented among the Evenki of Siberia ${ }^{8}$, the Chinese government started to reorganise the Evenki domestic economy. The first 
settlement with permanent housing for the Evenki was created in 1957 in Qiqian 奇乾 9 (Kalina 2006, p. 29), in the Argun Banner (Ch. A'erguna qi 阿尔古纳旗), next to the Russian border. Some Evenki were appointed as government members in the new local authorities set up for the settlement.

The four Evenki clans known at that time, the Sologon, the Buldotin, the Kaltakun and the Gudrin ${ }^{10}$, nomadised on four herding and hunting territories adjoining the village (NZBZ 1986, pp. 188-189), which were later used as demarcated boundaries for work units during collectivisation. The ethnic village was then relocated twice: in 1959 due to an ecological disaster and in 1965 for political reasons (see Xie in this volume). In the 1960s, recognizing the economic potential of reindeer antlers as a raw material for Chinese medicine, the local government attempted to convert small-scale reindeer herding into a collective state farm following the Soviet sovkhoz model. The thousand reindeer heads were collectivised and the herders used to sell the antlers to the local government annually in return for work points. In the 1960s, it was more difficult for the Evenki to access their herding and hunting territories, which had been reduced considerably by the growing forest industry and the arrival of many Han Chinese workers. The taiga was divided into forest areas used as sedentary spaces: numerous townships were built in the forest, such as Alongshan 阿龙山 and Jinhe 金河. The Evenki pastoral areas in northeastern Hulun Buir traditionally covered about 8,000,000 ha, but were successively reduced to $3,000,000$ ha in the 1980 s and finally to approximately 700,000 ha in the 1990s (Hao et al. 1994, pp. 44-45). Furthermore, public health, schooling, political and anti-religious campaigns were held under the leadership of Chinese cadres. Despite these new external constraints, the herders could maintain their domestic economy based on herding and hunting as long as the sale of reindeer antlers was financially viable for the local government. Following the decollectivisation process, the herders were given back their herds in 1984, although the antlers remained the local government's collective property until 2012. Since this date, the herders have been free to choose whether to sell the antlers to the local government or not. Most families prefer to deal with their own Han Chinese economic partners, since the prices are higher.

In the 2000s, while economic development remained a major leitmotiv in Chinese state policy, environmental degradation became an important issue, especially in the peripheral areas where "ethnic minorities" are scattered. Pastoral areas were not only potential economic resources: they also became fragile zones in need of state ecological protection. The “Open up the West” (Ch. xibu da kaifa 西部大开发) campaign, which started in 2001, highlighted the state's concern with conducting a policy that combined "environmental harmony", economic development and political legitimacy. One part of the "Ecological Migration" campaign was launched in 2003 in the Evenki area to protect the degraded forest zones and to enhance economic opportunities for locals. The resettlement of herders was followed by a ban on hunting to protect wild species and a big project to develop ethnic tourism. As mentioned above, due to the lack of lichen for their herds, the Evenki had to go back to their camps, situated from a few dozen to hundreds of kilometres from the ethnic village, in order to maintain viable herding. Years of hindsight and various published works on reindeer herding have shown that while the introduction of controlled production and territorial boundaries had important repercussions for Evenki social organisation and domestic economy (Bilik 
1996, pp. 65-66), they have still maintained nomadic practices, adjusting them to new economic, environmental and political factors.

In order to gain the best possible understanding of current Evenki nomadic practices, two spatial entities must be taken into account: the Aoluguya ethnic village and the camps.

\section{Two complementary spaces: the village and the camps}

\section{Aoluguya ethnic village}

17 Aoluguya Village is not only a sedentary administrative entity created by local authorities ${ }^{11}$ to provide a "modern life" for the Evenki people. It is also a part-time living area and one of the backbones of the Evenki's day-to-day social organisation. Located $4 \mathrm{~km}$ southwest from the city of Genhe 根河 (153,257 inhabitants in 2013'2), the village numbers 1,454 inhabitants, including 271 Evenki $^{13}$ divided into more than 20 nuclear families. Before the launch of the tourist project by the local authorities in 2008, Aoluguya was much like any other village built in northeastern China: rows of identical houses, a school, a local government building and one convenience store. Today, under the impetus of local policies to develop tourism, the village appears more "ethnic" since it combines contemporary architecture with reproductions of conical nomadic dwellings visited by tourists. The village is equipped with two-story wooden buildings, a retirement home, a museum dedicated to the culture of reindeer herding, an ethnic park ${ }^{14}$ situated a few hundred meters behind the village and, as of late, a large number of shops specialising in ethnic products. 
Figure 1. Main road of Aoluguya Village, July 2016

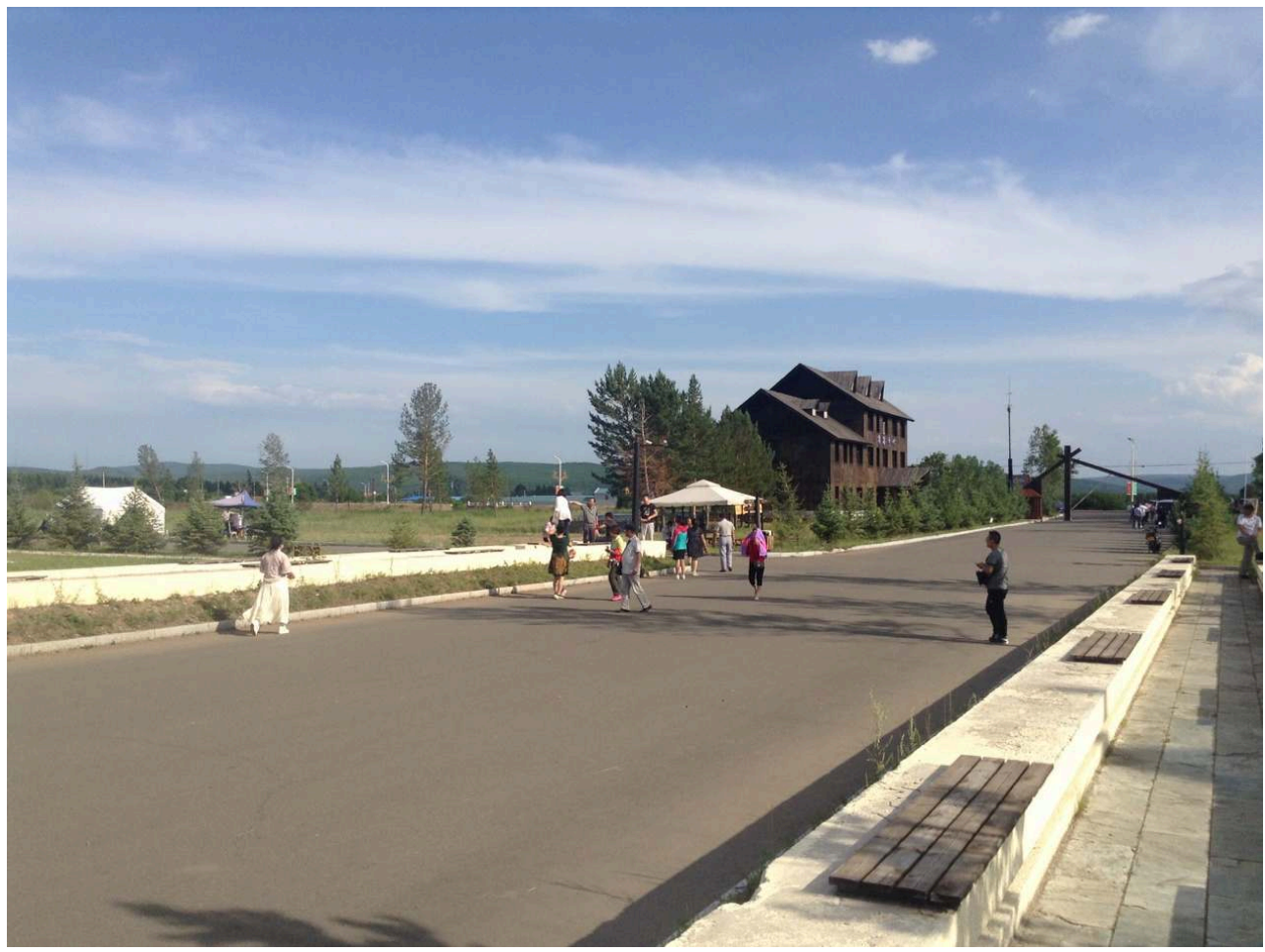

(c) Aurore Dumont, Aoluguya Village, July 2016

For the Evenki, before it is a tourist area or an "ethnic village", Aoluguya is the primary place to which they feel themselves to belong. Indeed, they explain that, over the course of generations, Aoluguya became the hometown of reindeer herders, where everyone found his own place. Although some people do not live for the whole year in the village, it remains a residential area with fundamental social, economic and administrative functions. Basically, after the "Ecological Migration" a house was allotted to every Evenki nuclear family.

As a governmental centre, the village is a place where "the political structure of the state meets a social community" (Humphrey \& Sneath 1999, p. 198). The local authorities play an important role in organising the village's social structure: they distribute household allocations, resolve potential conflicts regarding herding or other cases and organise collective events in which most people take part such as the “Auspicious Festival” (Ch. sebin jie 瑟宾节), the official Evenki celebration held annually on 18 June. Of equal importance is reindeer herding management, in which the local authorities take an active part. They provide herders with free equipment for their seasonal life in the camp (removable dwellings, solar panels and other useful furniture) vaccinations and food. They also buy antlers from herders who wish to sell them, and they participate in each nomadisation from one camp to another by providing the trucks and equipment necessary for moving. Even though members of the local authorities are spatially distant from the camps in the forest, they remain crucial decision makers.

The observations conducted in the village also offer a glimpse into the social relationships maintained between Evenki people within their community. Since the camps are situated far away from the village, thus complicating interactions between 
people, the village also acts as a gathering place. All the news related to life in the forest (reindeer herding, forest industry affairs, environmental problems, who left the camp and when, etc.) passes through the village when people meet there. When leaving the village, families disperse and set up tents in their respective camps.

According to the Evenki, Aoluguya forms the point of departure and arrival in all the itineraries of the herders when they go to or come back from the forest. The village also has a role in the herding decision-making process: all decisions related to reindeer herding are taken in the village (both by the herders and the local government). For example, herders and the local authorities meet in order to define a day for antler cutting or the date of the next nomadisation for the camp. It is also here where collective herding alliances between the different members of a given camp are formed and decisions are made with regard to the type of seasonal work to be done (for example, care of the new-born, milking, the repair of a tent, etc.). Social ties are expressed more prominently in the village than in the camps, or, at least, they offer a more precise instance of this social mechanism. Festive events provide a telling example of this logic: the whole community always gathers in the village for annual festivities, weddings or other social gatherings.

Since 2003, when Aoluguya was relocated $250 \mathrm{~km}$ to the south, the proximity with Genhe City has redefined the Evenki's daily lives. All social structures such as schools, hospitals, banks, supermarkets, etc. are situated in Genhe, the village providing a few grocery stores and shops for tourists open only during the summer. This is why all the Evenki children are enrolled in Genhe schools. Urbanisation also allows for various leisure activities much appreciated by the people (restaurants, karaoke) and commercial opportunities, since the Evenki can find some shops or Han Chinese partners to sell their products (mainly reindeer antlers). Vicinity to the urban space also implies remoteness from the camps. From the 1950s to the present day, reindeer herders have repeatedly survived the creation of the ethnic village, its multiple moves and its transformation into a hub of tourism during the summer. However, the community has had to adapt to each change by rearranging its territory, taking possession of different places and covering greater distances to reach camps in the taiga.

\section{The camp}

An older Evenki woman told me that in the 1960s, there were so many camps that it was impossible to count them all. In July 2016, there were 12 camps, but this number varies frequently according to people's needs, agreements and disagreements. Throughout the year, the Evenki divide their life and activities between the camp and the village. The length of their presence in the camp can extend from a few days to several weeks or months, depending on seasonal herding and individual constraints. A camp is organised into one to six tents, each being occupied by one person, a group of persons from the same nuclear family, a couple, relatives or even friends, depending on the season. During the winter, when reindeer require less care, only a few people, mostly men, are in the camp. Young women and children are largely absent during this period because children attend school in Genhe City. Thus, women's competences and responsibilities in the camp such as cooking, repairing clothes and tending to animals have also become men's tasks (Dumont 2015, p. 85). In contrast, summer is quite a busy season for herding and, recently, for tourism. Furthermore, as the children are on 
vacation, more people (from one or more families) share the camp from the beginning of July to the end of August.

For herders, the camp is a living space in the forest. Being spatially and symbolically detached from the administrative centre, it allows for a more flexible approach to herding management. In the taiga, the camp is laid out according to both administrative territorial limits and Evenki perceptions of the environment. The 12 camps are situated between 20 and $250 \mathrm{~km}$ away from the village ${ }^{15}$, along the railway line linking Genhe in the south to the township of Alongshan ${ }^{16}$ in the north. Even though they are scattered in the forest, each camp is connected either to a township or to Genhe by a road. This high level of urbanisation (compared to most of the Siberian situation, where the camps of the Evenki are situated hundreds of kilometres away from a township) highlights the effects of state economic development policies in the area. The state planners' perception of space determines the distribution and delimits the boundaries of available lands in the forest. As a result, the taiga is mapped into nine forest areas (Ch. linchang 林场), which are delimited by roads (Ch. gonglu 公路) at each township's entrance. The roads are further divided into numbered embranchments (Ch. chaxian 岔线) or other signalizations, small lanes trailing off into the taiga. Roads and forestry stations are numbered according to the territorial organisation, while mountains, valleys and townships have kept their Evenki-sounding names even after being transliterated and sinicised (toponyms bear Tungusic appellations, including Evenki, Oroqen and Manchu names $\left.{ }^{17}\right)$.

While the Chinese way conceives the forest as marked by boundaries, the Evenki way is based on a concept of multiplicity. By multiplicity, I mean a large range of resources, techniques and places conceptualised and used in different ways by the Evenki according to the requirements of herding and, to a lesser degree, hunting. Nowadays, the Evenki mainly use Mandarin terms or expressions to describe the environment and its surroundings - the young generations in particular only speak Mandarin. In this respect, the Evenki refer to the camp and its adjacent environment as "hunters' point" (Ch. liemin dian 猎民点), “forest” (Ch. senlin 森林) or “mountains” (Ch. shan 山). Regardless of the season, the camp is called "hunters' point" or "camp" in Chinese. Sometimes, the Evenki may also use the autochthonous term egdan, which designates the camp but literally means "taiga forest" or the "forest inhabited by nomads ${ }^{18}$ ". When one leaves the village for the camp, one says that one "goes uphill" (Ch. shangshan 上 山), while one would say that one "goes downhill" (Ch. xiashan 下山) when leaving the camp. Indeed, the area is mostly mountainous, and the metaphor of the mountain is always associated with a specific milieu that supports herding and hunting practices, one that is different from the city or the village. Going uphill means to reach the forest, the camp and its adjacent environment, pastures and hunting grounds.

The dwellings are diverse, differentiated by various terms and languages. The conical tent (djiu in Evenki, which also designates the household) is referred to via the Russian word meaning "tent" (palatka) by the Evenki and serves mainly as food store or a place for tourists to sleep. The modern rectangular tent (zhangpeng 帐篷 in Chinese) is the main living space during the summer months. Since 2013-2014, a third type of dwelling has been provided for free by the local government of Aoluguya to Evenki herders: a tent-covered truck (Ch. pengche 篷车) used during the winter ${ }^{19}$. In addition, the camp consists of a collective reindeer enclosure, a platform owned by each family for the 
storage of belongings (Evk. engnewun, Ch. cangku 仓库), a solar panel, a kennel for dogs and, for some families, a reserve of hay during winter.

Figure 2. A summer camp with reindeer, Pelagiia summer camp, Alongshan area, July 2016

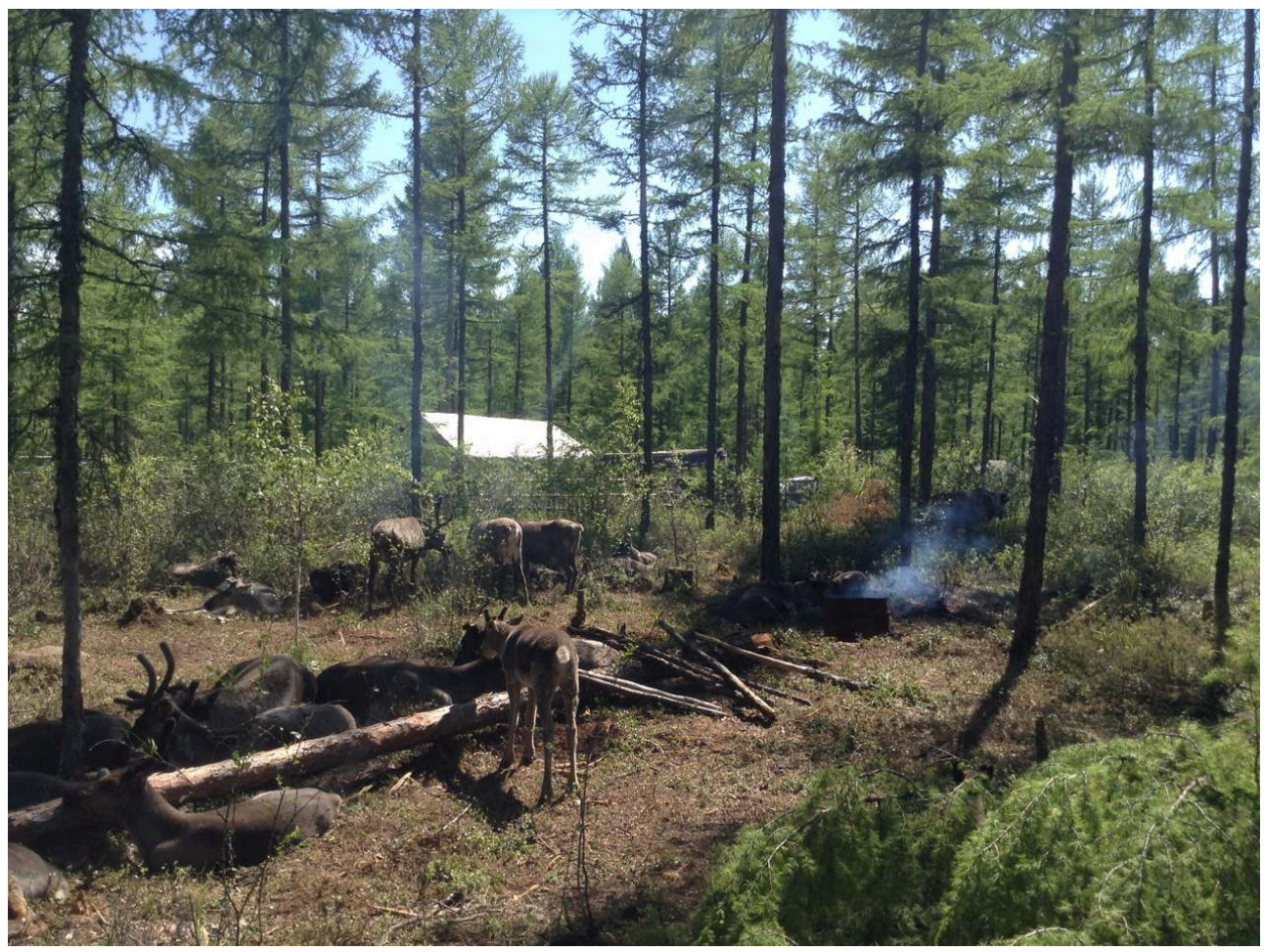

(c) Aurore Dumont, Alongshan area, July 2016

Figure 3. A modern rectangular tent, Pelagiia summer camp, Alongshan area, July 2016

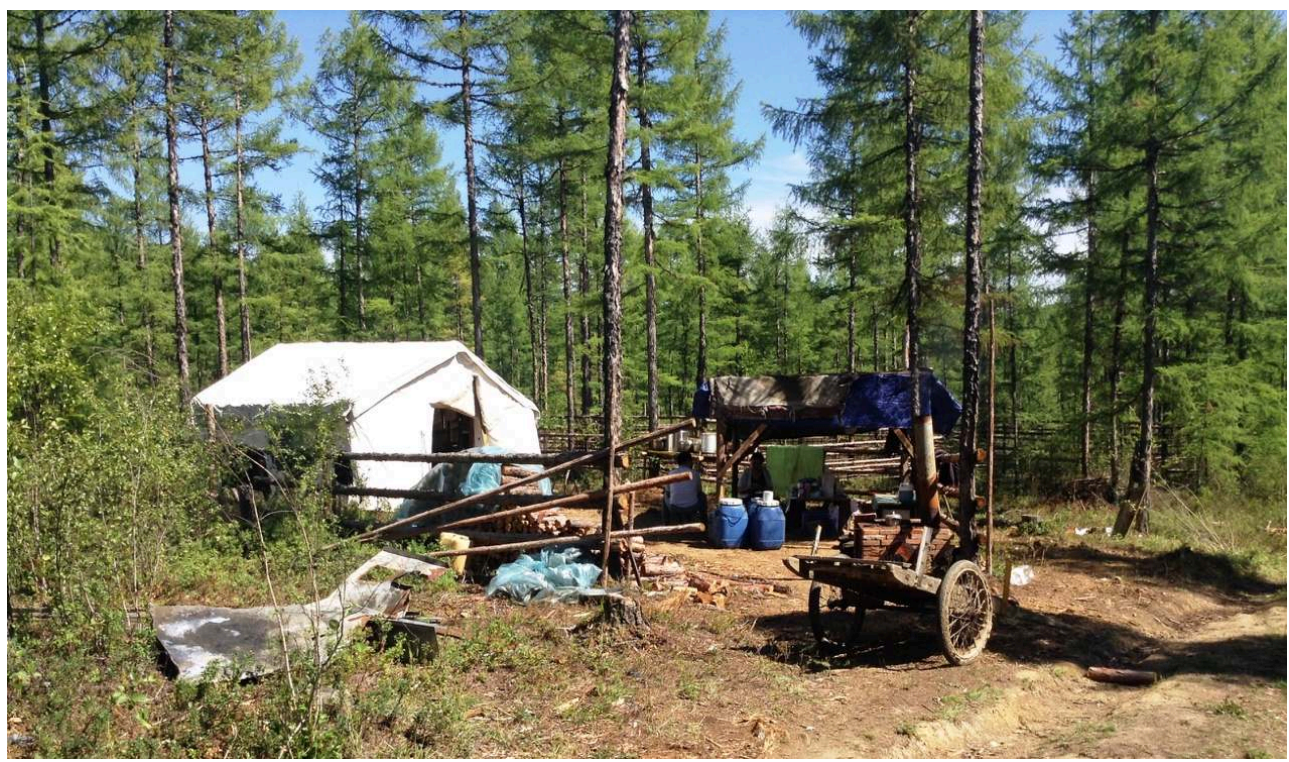

(c) Aurore Dumont, Alongshan area, July 2016

For the Evenki, the taiga ideally has no strict boundaries, unlike the administrative territories defined by fixed marks. At first sight, a camp may seem to be situated in a 
divided landscape shaped by local authorities for the needs of forest industry. Although they are codified, none of the areas in the forest are subject to regulatory constraints. The Evenki use many virgin areas without numbers, names and human occupation for herding and hunting. I consider that the two types of areas correspond to a dual spatial reading of the Evenki conception of environment. The first one, which I call "normed territory", bears the administration's stamp of demarcations and controls. This territory is divided into roads, regulated by signs and exploited and crossed by both Han Chinese (forestry workers, town inhabitants and tourists for the camps next to Aoluguya Village) and by the Evenki. The second one, which I designate by "autonomous territory", is inscribed in the "normed territory". At first sight, the "autonomous territory" appears to be isolated, devoid of administrative signs or human presence. However, the Evenki possess an extensive and comprehensive knowledge of this "autonomous territory". They know its shelters, resources and potential dangers, and also some of its secret hunting grounds (since hunting has been illegal since 2003). Furthermore, it possesses both visible and invisible signs that form a set of spatial and symbolic indicators by which the Evenki orient themselves within the forest. These signs may be the footprints of wild animals or domestic reindeer, a hill with a particular shape, small rivers or sacred spaces. For the Evenki, the "autonomous territory" is populated by various spirits or/and human souls. Furthermore some places must be avoided or, conversely, worshipped through ritual gestures and offerings. According to the emic understanding, this sacred landscape's entities have their own agency, which is reinforced by human action. Since the shaman has lost his/ her main functions in the taiga after the death of the last shaman in 1997, the interactions of Evenki herders with animals and spirits are now associated with different places and objects such as particular trees, fire, and are parts of various individual ritual practices. The latter are performed by individuals (sometimes on a day-to-day basis) and aim to preserve the community and guarantee success in hunting. They take various forms that include playing games and feeding spirits in the "autonomous territory" and in the tent, which in return will give access to game. The hunting ground is never crossed carelessly: the hunter carefully avoids certain places considered harmful to humans. For example, a place where a human being died will be systematically bypassed ${ }^{20}$. The places populated with spirits will be subject to certain rules: for instance, one has to feed them to get the opportunity to catch game.

The Evenki cover these two spaces, using both of them differently to maximise their opportunities, to meet the obligations of herding and the needs of hunting and to deal with bureaucratic restrictions. The "normed territory" is mainly used for commercial exchanges and supplies while the "autonomous territory" is used for its grazing and hunting areas, and as a ritual space.

Village and other urban areas on the one hand and camp site on the other are often considered by outsiders as two opposite realms. Although they are indeed geographically distinct spaces, they also overlap and are used by Evenki herders in complementary ways.

\section{Evenki mobility between different spaces}

Throughout the year, the Evenki reindeer herders undertake different trajectories between urban area and the camp in the taiga: from one camp to another, from one 
camp to a township, Aoluguya Village or Genhe City, and vice versa. These mobility frameworks are not exclusive categories; they are established complementarily and highlight how Evenki respond to external pressures and new challenges such as summer tourism by adopting various forms of mobility.

\section{Choosing a camp in the forest}

Strictly speaking, nomadisation implies the moving of the nuclear family and its herd from one camp to another according to seasonal herding and hunting patterns. Before the 2003 "Ecological Migration", the Evenki used to camp in a new location almost every week and nomadisation was carried out on the backs of reindeer. At that time, there were no solar panels, televisions or iron beds and the equipment was relatively light. Nowadays, the Evenki nomadise approximately two to four times a year according to seasonal requirements ${ }^{21}$, the choice of the nuclear family and summer tourism for some people. While some herders choose to nomadise one time in the winter and a second time in the summer, others move every season.

Before forming a new camp in the forest, the Evenki have to take into account two fundamental parameters: the first is dictated by reindeer herding, while the second is linked to the bureaucratic division of the forest.

Following the seasons, the renewal of resources requires the selection of an area suitable to the herd's nutritional requirements. Indeed, a variety of rules and spatial organisation govern the selection of a new camp. Since hunting is banned and performed more occasionally than before, the choice of a camp area depends primarily upon the nutritional needs of the reindeer at the expense of hunting activities. First, herders must find a sheltered zone to protect reindeer from external dangers such as truck passage and Chinese poachers coming from adjacent townships. They ideally prefer a territory nestled at the centre of the forest where the camp is not too visible. The richness of the soil in terms of lichen and the proximity of a water source are crucial. Once the most favourable area has been chosen, the Evenki organise their camp in an area marked out in advance by the men. This consists of opening new pathways by cutting away branches and other obstacles.

At the end of the spring in April, the Evenki are busy with the reindeer parturition, which requires a daily gathering of the herds in the camp and the construction of enclosures. In May, when the antlers have grown, an experienced herder cuts them, travelling to each camp and then bringing them in the village. Daily milking (Evk. sielda) falls to women. Between June and August, men build fires in the centre of the camp to protect the reindeer against mosquitoes. July and August are also the season of mushroom picking and constructing or repairing tent structures.

As a large amount of wood is required for heating the tents and cooking during the winter (starting from the end of September), priority is given to areas with larch that are situated next to the hunting grounds. Since the herd require less care, fewer people remain in the camp during this season. Every day or every three days, men go to look for their reindeer (which must stay together), walking up to 5 or $10 \mathrm{~km}$. Other daily activities include chopping wood and cutting ice from the frozen river for drinking water. The water is used for cooking and for making tea or hot water. mainly practice two types of hunting: tracking and trapping. The first is used to find 
furbearing animals and deer, while the second is mainly reserved for capturing rabbits. The ban on hunting was a dramatic event for the Evenki because "hunting is one of the first activities of the man, and we have learned so much from animals", as one skilled hunter once told me in 2011. While conducting field research among the Evenki in the late 1950s, Chinese scholars asked the following question to an Evenki hunter: "What would you do if the game was to disappear?" The hunter replied: "If there is no more game in the future, well then we will see" (NZBZ 1986, p. 178). Fifty years later, game has been effectively rarefied by decades of industrialisation and over hunting by newcomers from other provinces. Since hunting became an illegal activity, hunters have had to take all necessary precautions and prefer to go through "autonomous territory" for hunting instead of venturing into "normed territory".

Apart from environmental and herding needs, the Evenki have to deal with an administratively defined space: this requires adaptive strategies each time they move from one camp to another. Upon each nomadisation, the Evenki have to select a new camp area according to the territorial boundaries imposed by the Forestry Department of Genhe (Ch. Genhe linye ju 根河林业局 ${ }^{22}$ ). Founded in 1954, this department is in charge of some 632,000 ha of forest. More than 5,600 people (mainly Han Chinese) work for this organisation, which deals with development issues as well as the protection and management of the forest. Since some areas are reserved for woodcutting ${ }^{23}$, herders must be careful not to hinder the passage of forest workers. At the same time, they need to be able to access areas rich in wood for their own consumption. Moreover, the camp must be easily identifiable for reasons of safety and easy access. The camp should be precisely located at the end of a numbered embranchment and not far from the road. An Evenki technique used to mark the camp location consists of hanging a band of coloured cloth in a tree ${ }^{24}$. This proximity to the road allows herders to move easily and permits the Aoluguya local authorities to reach the camp (to deliver supplies, lead journalists or accompany a veterinarian). In addition, forest employees are always kept informed of camp locations and all those who regularly go through the forest, namely seasonal workers, forestry workers and town residents with whom the nomads maintain market relationships. Reaching a camp requires that one goes through a township and a forest station and then takes a main road and several branches. The following two figures provide quite different insights into how annual nomadisations are carried out according to the aforementioned environmental parameters and bureaucratic constraints. They show the cases of the two Dongxia camp and the Dawa camp. Each camp is named by both the local authorities and the Evenki after the camp leader's first name. The camp leader is always Evenki and is chosen by the other camp members.

The Dongxia camp is less than $40 \mathrm{~km}$ from Genhe City. The nomadisation is carried out annually two to three times in July and in September along embranchment number 36. The summer and winter camps are both located between the main road and embranchment 36, close to streams. The average annual distance covered by the camp members ranges from 3 to $5 \mathrm{~km}$. This example highlights the considerable reduction of both the area of nomadisation and mobility. For the sake of comparison, Alexandra Lavrillier has noted that the Evenki of Southeastern Siberia can cover up to 1,000 km annually (Lavrillier 2006, p. 4). 


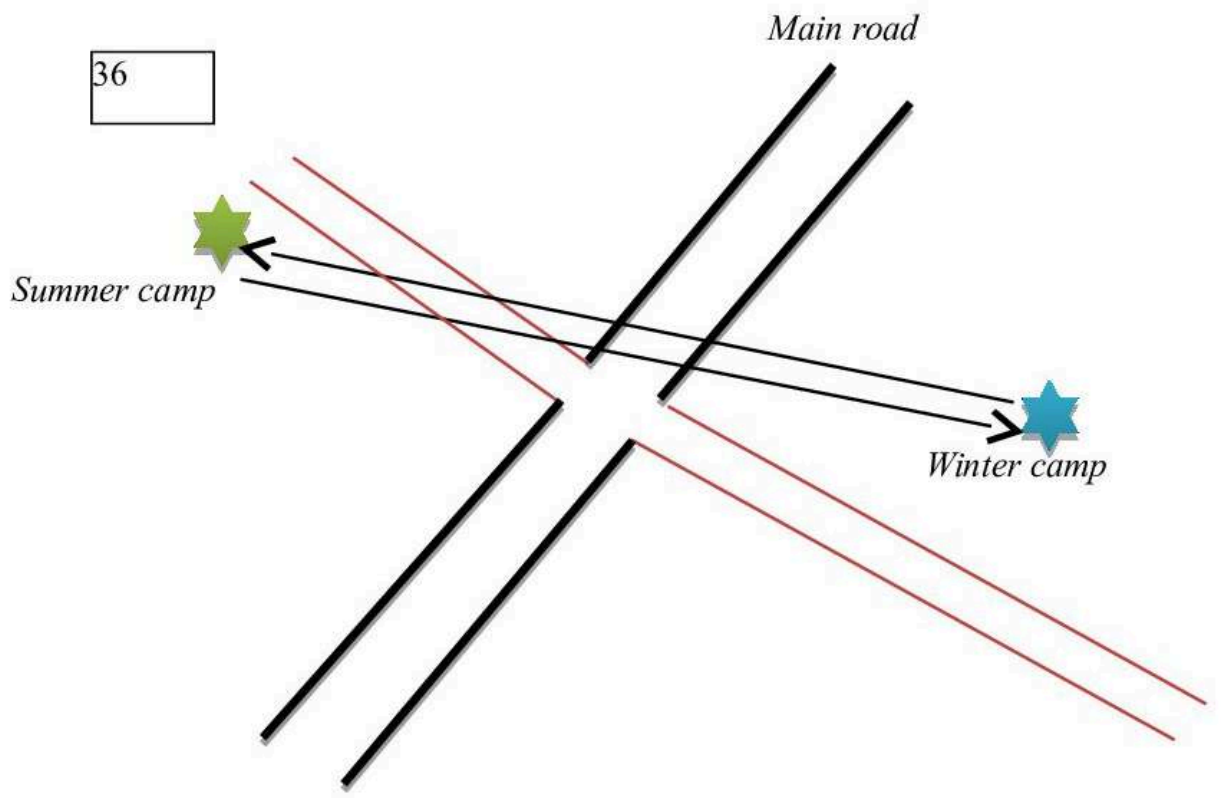

(c) Aurore Dumont, according to the explanations from members of the Dongxia camp members, December 2009

The second figure shows quite a different situation.

The Dawa camp is $70 \mathrm{~km}$ from Jinhe township and about $150 \mathrm{~km}$ from the village. Its annual trajectory of nomadisation is based on a circle made up of five different camp zones. While the same route is followed during the winter nomadisation, the spring and summer routes alternate from one year to the next. Regardless of the camp location in the forest, administrative territorial rules require that hills, mountains or valleys are not crossed since they delimit the area of nomadisation. The Dawa routes remain stable and defined by territorial boundaries, as is the case for other people's nomadisations. 
Figure 5. Annual nomadisation of the Dawa camp in 2013

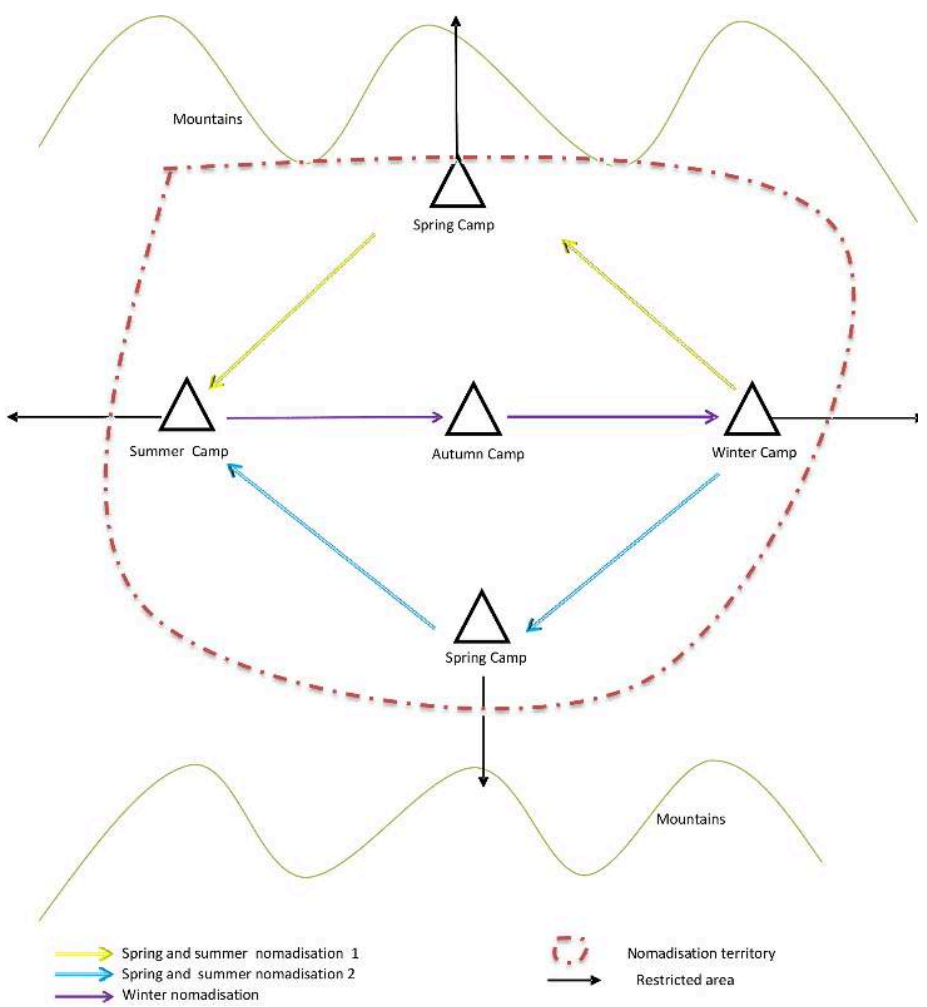

(c) Semen Gabyshev, adapted by Aurore Dumont, according to Dawa's explanations, July 2014

\section{Moving from one camp to another}

People move from village to camp and from one camp to another. As mentioned earlier, the ethnic village is the arrival and departure point for every journey. Once the new site is chosen by men who went off to look for it, some people remain in the camp to prepare materials while the other members go to the village to gather things, find people who can help to pack them into a tent truck. The ease with which herders can switch from one space to another is tied to growing motorisation. The abandonment of reindeer as pack animals to nomadise in exchange for all-terrain vehicles, which are considered to be more practical when carrying increasingly heavy herding equipment, dates back to the beginning of the 1990s. While the equipment is transported by car, herders reach the new campsite by foot with their herd, which is sometimes also transported by four-wheel drive and in trucks. Everywhere in Hulun Buir where roads are surfaced, motorised vehicles have changed the nature of movement. Herders perform most of their journeys by all-terrain vehicle, car, motorcycle, tractor or truck. This phenomenon is not unique to the pastoral regions of China. In Chukotka, tracked vehicles are used to transport heavy goods over long distances during the transhumance (Vaté 2013, p. 77). China's reindeer herding management appears to be a unique case in the world where the animals can be transported by car and so on over such short distances.

Staying in the same camp site for an entire season means that men and especially women have become less mobile. Whether in the forest or between different spaces, men are generally much more mobile than women. Women stay for a long period of 
time in the village, taking care of the children's education. When they are at the camp, women are in charge of domestic tasks in the tent and feeding reindeer, which requires less mobility. Nevertheless, while mobility dictated by herding and hunting has been largely reduced both in terms of distance and frequency, other trajectories are characterised by the opposite phenomenon.

\section{Other trajectories}

Apart from annual nomadisations conducted within the forest, that is to say between two camps, the Evenki also travel hundreds of kilometres per year for different purposes. While these movements are difficult to prioritise, it is possible to determine common trajectories. The first takes place between the camp and the townships for the purpose of selling merchandise and grocery shopping. The townships are important places for herders: they are areas for refuelling and making purchases, sales and exchanges of some hunting products and reindeer antlers. Furthermore, they are also meeting places. These townships (Ch. xian 县 or zhen 镇 depending on the size) are so often frequented by the Evenki people that the inhabitants know them all: every herder, man or woman, goes to his or her own grocer. Reaching a camp in the taiga requires passing through a township, which marks the beginning of the entry into the forest area. Before reaching it, herders buy the necessary supplies: meat, rice, vegetables and other materials. Similarly, when returning to Aoluguya, they must go through a township, as this is the only way back.

In the field, I observed that these journeys, which are different from nomadisations, are undertaken approximately every week or every two weeks. Thus, the reindeer herders who go once a month to the Alongshan camp, which is located around $200 \mathrm{~km}$ from the village, travel over $4,800 \mathrm{~km}$ every year. The means of locomotion are also very important. The train connecting Genhe City to Alongshan township remains the preferred means of transportation for the herders. Upon their arrival in the township, they use taxis to reach the camp. For less remote camps (between 20 and $40 \mathrm{~km}$ ), the Evenki often use the car provided by the local government. Every month, the government replenishes each camp with food supplies (such as oil, rice and flour). In addition, as mentioned earlier, the city is part of the herders' life. Located only $4 \mathrm{~km}$ from Aoluguya Village, Genhe provides a number of elements to herders who live in the village: first, one can buy everything that is not provided in the township, such as specific foods, mobile phones and computers. The city has the reputation of having a wider range of cheaper goods. Moreover, it is synonymous with urban festivities, such as karaoke and restaurants. Thus, herders like to go regularly to Genhe, which is easily reachable by taxi during the winter or by motorcycle or bicycle during the summer.

6 Herders want to have access to urban services, like the rest of the population. As stressed by Humphrey and Sneath, the existence of cities in the steppes is not incompatible with the maintenance of mobile pastoralism (Humphrey \& Sneath 1999, p. 300).

\section{Tourism mobility}

Furthermore, since 2012, summer tourism has affected the herding management and the annual nomadisations of some herder families. Still in its nascent phase in the 
mid-2000s, tourism is nowadays a well-established local industry in which many herders take an active part for economic purposes. The tourists are mainly Han Chinese coming from other provinces of China. Organised into groups and led by a Chinese or Evenki guide, the tourists normally make a whole tour of the Hulun Buir area. The trip starts in the southern grasslands of Hulun Buir, where Mongol and other Evenki groups live, and finishes in the northern forest among the reindeer herders. Tourists come to see "exotic ethnic minorities" and the only reindeer herders in the country. Thus, the tourists, who can number more than 150 people a day, visit the village and its museum, the ethnic park and the forest camps. Tourists usually do not stay more than an hour in the camp. They pay to be allowed to take pictures of reindeer, conical tents and the Evenki wearing their ethnic costumes (Dumont 2016, p. 289). The tourists also pay camp entrance fees and buy souvenirs, which are the main sources of summer tourism income for the herders.

In July 2016, out of a total of 12 camps of reindeer herders, six were opened to tourists during the summer period from the beginning of June to the end of August. Before the summer season, the Evenki families must choose a proper place for grazing their herds and hosting tourists. As we have seen, the Evenki ideally prefer areas that are far away from the biggest urban centres; however, during the summer season, these two spatial parameters are reversed. To be reachable by tourists, the camps must be located less than $20 \mathrm{~km}$ away from Aoluguya Village. Besides the spatial arrangement of the summer camp, the regular flow of tourists has led the Evenki herders to move more frequently during the summer season. These journeys are mainly conducted between one camp and the village and between the village and Genhe City. They are carried out several times a week, depending on the desires of the tourists and the needs of herders. When the summer season ends, the herder families go back with their herd to the northern areas for the winter season. The different movements outlined above raise several questions regarding herd's viability. The tourism mobility does not go without causing some damage to the well-being of the reindeer herds. According to six families of herders engaged in tourism, the poor quality of the vegetation, the pollution and the flow of people coming every day to the camp cause irreversible damage to the reindeer and the surrounding environment. The herders engaged in tourism explain their choice in terms of financial income. Indeed, summer tourism represents a welcome financial supplement in a place where the principal income comes from governmental subsidies, the sale of reindeer antlers and illegal hunting.

\section{Are the Evenki herders still nomads?}

Evenki herders move two to four times a year from the camp to the village, and several times from the camp to a township and from the village to the township. This illustrates extensive mobility between these different spaces throughout the year. These different levels of spatial mobility follow constantly changing patterns, suggesting that herders' activities are continuously interacting with various spatial, political and economic environments, thus giving rise to new nomadic and sedentary practices. However, nomadic practices cannot be reduced to the mobility parameter. We have shown that, as part of an ongoing process, nomadic practices encompass mobility, herding techniques, skills, beliefs and environmental knowledge. The two categories of space, "normed territory" and "autonomous territory", analysed in the 
present paper underline the way the Evenki community uses them in a complementary manner, being alternately mobile and less mobile.

For instance, in the Tibet Autonomous Region, Angela Manderscheid has shown how the Tibetan pastoralists of Amdo revived their "nomadic lifestyle" based on a traditional economy of high yak herding by returning to a subsistence-based economy and adapting the features of the revived lifestyle to changed ecological, political and economic conditions (Manderscheid 2002).

51 Chinese scholars have carefully examined the issue of nomadism in the pastoral areas of the PRC. Since 2003, a number of works have been published on the "Ecological Migration" of 2003 among the Evenki reindeer herders and its impact on their "traditional way of life". Before 1949, the Chinese term youlie 游猎 (literally: "to nomadise" and "to hunt") was mainly used to refer to reindeer herding and hunting practices. It was often associated with the idea that the herders were moving “following water and grass" (Ch. sui shuicao er qianyi 遂水草而迁移). Since the 1950s, this Chinese conception of "traditional nomadism" has been constantly changing, especially since a growing number of settlements have been created for nomads. In an article devoted to the present situation of the Evenki reindeer herders, Qi has provided a framework, classifying the Evenki into three categories according to the degree of their mobility and their social status: the "mobile [nomads]" (Ch. yidong weizhu 移动为 主), whose lifestyle is "traditional", mainly based on nomadism and whose income principally comes from the sale of reindeer antlers; the "half-mobile and halfsedentarised [nomads]" (Ch.ban yidong ban dingju 半移动半定居), whose lifestyle is "modern" and whose income comes from salaries (for those with official and regular incomes); and the "sedentary people" (Ch. dingju 定居), whose lifestyle is “modern" and whose income depends on government aid (Qi 2006, p. 100). However, the complex situation of the Evenki makes difficult to support such a rigorous categorisation. Indeed, a significant proportion of supposedly "sedentary people" actually possess reindeer herds and salaries, while some "mobile nomads" have neither reindeer nor revenues from antler sales; nonetheless, they are engaged in reindeer herding. Thus, in Northeast China, the Evenki live in a common social sphere. In contrast, Alexandra Lavrillier demonstrates that among the Evenki of Southeastern Siberia, despite the circulation of some individuals between camps, villages and towns, Evenki nomadic herders, villagers and townspeople do exist and function as distinctive and different social spheres (Lavrillier 2005, pp. 169-413 et passim).

For the Evenki of China, the reindeer herd is a form of both material and symbolic capital, and most human activities relate to reindeer in one way or the other. Whatever its nature, reindeer herders pursue the same goal: the optimisation of nomadic practices through constantly modified knowledge. As a social and economic system, herding and the antler business represent both the main sources of income for the herders and their "cultural values". Mobile or less mobile, living alternately in ethnic village and in the camp, all the Evenki consider reindeer essential for their existence. As they often say: "without reindeer, the Evenki would not exist". 


\section{BIBLIOGRAPHY}

Bilik, N. 1996 Emotion gets lost. An Ewenki case, Inner Asia 1(1), pp. 63-70.

Brandišauskas, D. (this volume) The gluttons of eastern Siberia. Spirits, poachers, and cannibals in Evenki perceptions, Études mongoles \& sibériennes, centrasiatiques \& tibétaines 49 [online, URL: http://journals.openedition.org/emscat/3441, accessed 20 December 2018].

Cencetti, E. 2010 Tibetan plateau grassland protection. Tibetan herders' ecological conception versus state policies, Himalaya 30(1-2), pp. 39-50.

Central Institute of Ethnic Administrators (Zhongyang minzu ganbu xueyuan 中央民族干部学院) [online, URL: http://www.mzgbxy.org.cn/mzss/html/?3259.html, accessed 20 April 2016].

Chinese National Census, 2010 [online, URL: www.stats.gov.cn, accessed 5 April 2016).

Dumont, A. 2015 The many faces of nomadism among the Reindeer Ewenki of Inner Mongolia. Uses of land, mobility and exchange networks, in A. Kolås \& Y. Xie (eds), The Ewenki of Aoluguya: Reclaiming the Forest (Oxford, Berghahn Books), pp. 77-97.

2016 Le patrimoine culturel du renne. Pratiques touristiques et trajectoires nomades chez les Évenk de Chine (Mongolie-Intérieure), Autrepart. Revue de sciences sociales au Sud 78-79, pp. 277-291.

Dyson-Hudson, R. \& N. Dyson-Hudson 1980 Nomadic pastoralism, Annual Review of Anthropology 9, pp. 15-61.

Fraser, R. 2010 Forced relocation amongst the Reindeer-Evenki of Inner Mongolia, Inner Asia 12, pp. 317-345.

Gladney, D. C. 2004 Dislocating China. Muslims, Minorities, and Other Subaltern Subjects (London, Hurst \& Company).

Hao Shiyuan 郝时远, Zhang Shihe 张世和 \& Naribilige 纳日碧力戈 1994 Xunlu zhi xiang Aoluguya Ewenke zu liemin xianzhuang yanjiu - 34 nian hou de zhuizong diaocha 驯鹿之乡敖鲁古雅鄂温克族猎 民现状研究-34年后的追踪调查 (1960-1994) [Research on the current situation of Evenki minority's hunters in the reindeer village of Aoluguya. Continued investigation after 34 years (1960-1994)] (Beijing, Zhongguo shehui kexueyuan minzu yanjiusuo).

Heberer, T. 1989 China and Its National Minorities. Autonomy or Assimilation? (Armonk, M. E Sharpe).

Heyne, G. 1999 The social significance of the shaman among the Chinese Reindeer-Evenki, Asian Folklore Studies 58, pp. 377-395.

Humphrey, C. \& D. Sneath (eds) 1999 The End of Nomadism? Society, State and the Environment in Inner Asia (Durham, Duke University Press).

Kaigorodov, A. M. 1968 Èvenki v Trëhrech'e. (Po lichnym nabliudeniiam) [The Evenki of the Three Rivers area. (Personal observations)], Sovetskaia Ètnografiia 4, pp. 123-131.

Kalina 卡丽娜 2006 Xunlu Ewenke ren wenhua yanjiu 驯鹿鄂温克人文化研究 [Research on Reindeer Evenki's culture] (Shenyang, Liaoning renmin chubanshe).

Lavrillier, A. 2005 Nomadisme et adaptations sédentaires chez les Évenks de Sibérie postsoviétique : 'jouer' pour vivre avec et sans chamanes. PhD thesis (Paris, École Pratique des Hautes Études).

2006 S'orienter avec les rivières chez les Évenks du Sud-Est sibérien. Un système d'orientation 
spatial, identitaire et rituel, Études mongoles \& sibériennes, centrasiatiques \& tibétaines 36-37, pp. 95-138.

Lavrillier, A., A. Dumont \& D. Brandišauskas (this volume) Introduction. Human-nature relationships in the Tungus societies of Siberia and Northeast China, Études mongoles \& sibériennes, centrasiatiques \& tibétaines 49 [online, URL: http://journals.openedition.org/emscat/3088, accessed 20 December 2018].

Lindgren, E. J. 1930 North-Western Manchuria and the Reindeer-Tungus, The Geographical Journal 75(6), pp. 518-534.

1938 An example of culture contact without conflict. Reindeer Tungus and Cossacks of NorthWestern Manchuria, American Anthropologist, new series 40(4), pp. 605-621.

Manderscheid, A. 2002 Revival of nomadic lifestyle: a survival strategy for Dzam Thang's pastoralists, in T. Huber (ed.), Amdo Tibetans in Transition. Society and Culture in the Post-Mao Era (Brill, Leiden), pp. 271-290.

NZBZ (Neimenggu zizhiqu bianjizu 内蒙古自治区 编辑组) 1986 Ewenke zu shehui lishi diaocha 鄂温 克族社会历史调查 [Social history research investigations on Evenki] (Hohhot, Neimenggu renmin chubanshe).

NZEY, HEY (Neimenggu zizhiqu Ewenke yanjiuhui 内蒙古自治区鄂温克研究会, Heilongjiang sheng Ewenke yanjiuhui 黑龙江省鄂温克研究会) (eds) 2007 Ewenke diming kao 鄂温克地名考 [Research on Evenki toponyms] (Beijing, Minzu chubanshe).

Qi Huijun 祁惠君 2006 Xunlu Ewenke ren shengtai yimin de minzuxue kaocha 驯鹿鄂温克人生态 移民的民族学考察 [Ethnological investigation on the ecological migration of Evenki reindeer herders], Manyu yanjiu 1, pp. 98-105.

Shirokogoroff, S. M. [1929] 1966 Social Organization of the Northern Tungus (Oosterhout, The Netherlands).

Stépanoff, C., C. Ferret, G. Lacaze \& J. Thorez (eds) 2013 Nomadismes d'Asie centrale et septentrionale (Paris, Armand Colin).

Tsui, Y. 2012 Swinging between nomadism and sedentarism: a case study of social and environmental change in the nomadic society of the Altay steppes, Xinjiang, Nomadic Peoples 16(1), pp. 50-67.

Vaté, V. 2013 La chenillette en Tchoukotka, in C. Stépanoff, C. Ferret, G. Lacaze \& J. Thorez (eds), Nomadismes d'Asie centrale et septentrionale (Paris, Armand Colin), p. 77.

Xie Yuanyuan 谢元媛 2010 Shengtai yimin zhengce yu difang zhengfu shijian : yi Aoluguya Ewenke shengtai yimin weili 生态移民政策与地方政府实践: 以敖鲁古雅鄂温克生态移民为例 [The ecological migration governmental policy and its application by local authorities: the Aoluguya Evenki case study] (Beijing, Beijing daxue chubanshe).

2015 Ecological Migrants. The relocation of China's Ewenki Reindeer Herders (New York, Oxford, Berghahn).

(this volume) From hunters to herders. Reflections on the "Ecological Migration" of the Chinese Evenki reindeer herders, Études mongoles \& sibériennes, centrasiatiques \& tibétaines 49 [online, URL: http://journals.openedition.org/emscat/3414, accessed 20 December 2018].

Yong Tianzhen 永田珍 [Nagata, H.] [1969] 1991 Xunlu Elunchun 驯鹿鄂伦春 [The Orochen Reindeer herders], translated from Japanese by Ao Denggua 奥登挂 in Neimenggu zizhiqu ewenke yanjiuhui (ed.) Ewenke zu yanjiu wenji 鄂温克族研究文集 [Collected works on Evenki nationality], II (Nantun, Neimenggu zizhiqu ewenke yanjiuhui), pp. 339-365. 


\section{NOTES}

1. According to China's ethnic policy, areas with a considerable concentration of "ethnic minorities" have been given special political and administrative status. The "ethnic villages" (Ch. minzu xiang 民族乡) are one of these administrative units designated for "ethnic minorities". They were mainly created in the 1950s and 1960s, when the ethnic groups were still a majority. The growing number of Han Chinese has led the "ethnic minorities" to become a minority in these "ethnic villages".

2. For more details about ethnographers who have conducted fieldwork among the Evenki reindeer herders of China, see the introduction.

3. I conducted my fieldwork mainly in Mandarin.

4. The Evenki reindeer herders are officially part of the "Evenki ethnic minority" which is composed of three sub-groups: the reindeer herders, the Solon and the Khamnigan. While the reindeer herders live in the forest zone, the Solon and the Khamnigan live in the grasslands areas near their Mongol neighbours. According to the 2010 Chinese National Census, the total population of the Evenki amounts to 30,875 people. After their merger with the official Evenki entity, no population figure is available for the Evenki reindeer herders. I thus give an approximate number provided by the local authorities. For more details about the three Evenki sub-groups of China, see the introduction.

5. For a detailed analysis of the "Ecological Migration" process and its social impact, see Xie 2010, 2015, pp. 85-124, Fraser 2010 and Xie in the present volume.

6. Regarding the large size of pastoral areas, including both forest and steppe zones in Hulun Buir, territorial planning was administered differently. In the present case study, I refer only to the forest zone of the Genhe and Argun river area, where the Evenki herders live nowadays.

7. For a comprehensive analysis of the ethnic policies pursued in PRC, see Gladney 2004 and Heberer 1989.

8. The policies in this part of the Soviet Union were effectively carried out from the 1940 s and the 1950s, depending on the region. For more details, see Lavrillier 2005, pp. 102-140.

9. At this time, Qiqian was better known by its Russian appellation "Ust-Urov", named after the border village on the Russian side.

10. Today, these four clans are still known and have many representatives among the Evenki. They have been transformed into the Chinese family names Suo 索 (Sologon), Bu 布 (Buldotin), Ka 卡 (Kaltakun) and Gu 固 (Gudrin).

11. Nowadays, the mayor of Aoluguya Village is a Solon Evenki. The other people who work in the local government are both Evenki and Han Chinese.

12. According to the Ministry of Public Security quoted by the Genhe government's online website: www.genhe.gov.cn (last accessed on 25 July 2018).

13. The total population includes the other two villages under the jurisdiction of Genhe City: Sanchejian 三车间 and Jialaga 加拉坵. Excluding the Evenki, the population is composed of Han Chinese (768) and eight other "ethnic minorities" (Manchu, Mongol, Hui, Oroqen, Russian, Dahur, Korean and Li), according to data provided by the Central Institute of Ethnic Administrators (Ch. Zhongyang minzu ganbu xueyuan 中央民族干部学院).

14. The ethnic park, officially called the "primitive tribe's tourist park" (yuanshi buluo lüyoudian 原始部落旅游店) is the first Evenki recreational camp built in the area. Financed by the local authorities, this "open-air museum" offers attractions and reindeer exhibitions.

15. In 1994, when the Evenki were living in their former village, Naran Bilik noted that the camps were about $60 \mathrm{~km}$ away from the village (Bilik 1996, pp. 65-66).

16. Alongshan is the biggest township (Ch. zhen 镇) of Genhe area. It was built in 1968 following the development of the forest industry (NZEY, HEY 2007, p. 391). 
17. For example, Gadzha (Ch. Galaya 嘎拉雅) means “ferocious bird” or “giant bird" in Evenki. It is a small hamlet constructed in 1959 and situated to the north of Genhe City. Haolibao 好里堡, another small hamlet $4 \mathrm{~km}$ away from Genhe City, is the Chinese transcription of the Evenki term kolbo, which is a storage cache.

18. Personal communication by Alexandra Lavrillier about the Southeastern Siberian and Chinese Evenki reindeer herders.

19. The covered truck is a new type of mobile dwelling used by a number of pastoralists and herders. It first appeared in the steppe areas of Hulun Buir in the mid-2000s to replace the Mongol yurt. Since 2013-2014, the local government of Aoluguya has provided the Evenki reindeer herders with this new type of mobile home for the winter. Each camp is given a covered truck for free. While some families have chosen to live in the covered trucks during the winter, others still prefer to stay in their tents.

20. For a comparison with local spirits and ritual practices among the Russian Evenki of Transbaikal region, see Brandišauskas in the present volume.

21. In the words of Lavrillier (2005), the "Evenki calendar" in Siberia is composed of five seasons: the summer (Evk. diugha), the autumn (Evk.bolo), the winter (Evk.tughe), the first spring (Evk. nelkini) and the second spring (Evk. niengneni). Each season corresponds to specific pastoral and/or hunting activities. This calendar is known among the older reindeer herders in China.

22. See the official website: http://www.ghlyj.com.

23. Woodcutting has been regulated since 2003 .

24. The Evenki of Southeast Siberia use these ribbons (Evk. ulganivun) for offerings to the local spirits with a second function of "marking the camp space" (Lavrillier 2005, pp. 472-478).

\section{ABSTRACTS}

The last six decades of Chinese state policies has led to the transformation of the Evenki reindeer herders' domestic economy, a more systematic use of fixed homes and the reduction of the grazing areas. Paradoxically, the herders' mobility has become more flexible and extensive, while herding skills remain a fundamental component of their way of life. The present paper explores the contemporary nomadic practices of the Evenki by examining their annual moves between village and camp. The constant movement of the herders between these two complementary spaces reflects their strategies for adapting to ecological and political challenges.

Les politiques étatiques chinoises de ces six dernières décennies ont conduit à la transformation de l'économie domestique des Évenks éleveurs de renne, à une utilisation accrue d'habitats fixes, et à la réduction des zones de pâturage. Paradoxalement, la mobilité des éleveurs est devenue plus flexible et étendue, tandis que les compétences liées à l'élevage demeurent une composante fondamentale de leur mode de vie. Le présent article étudie les pratiques nomades contemporaines des Évenks en examinant leurs mouvements annuels entre village et campement. Les mouvements constants des Évenks entre ces deux espaces complémentaires reflètent leurs stratégies d'adaptation aux défis écologiques et politiques. 


\section{INDEX}

Mots-clés: Évenk, élevage, nomadisme, pastoralisme, mobilité, sédentarisation, politiques publiques, minorités ethniques, Chine, Mongolie-Intérieure

Keywords: Evenki, herding, nomadism, pastoralism, mobility, sedentarisation, public policies, ethnic minorities, China, Inner Mongolia

\section{AUTHOR}

\section{AURORE DUMONT}

Aurore Dumont completed her PhD in anthropology at École Pratique des Hautes Études, Paris in 2014. Her doctoral research explores the contemporary pastoral practices of Evenki people in Inner Mongolia, People's Republic of China. Between 2015 and 2017, Aurore Dumont was a postdoctoral fellow of the Centre for China Studies at the Chinese University of Hong Kong. She is currently a postdoctoral fellow at the Institute of Ethnology in Academia Sinica, Taiwan. Her current research focuses on the ritual practices (oboo cairns and shamanic graves worships) among the Tungus and Mongol societies of Northeastern China from the Late Qing up to the present.

auroredumont@gmail.com 